\section{SCIENTIFIC WORKERS AND THE CHEMICAL INDUSTRIES}

$\mathrm{D}$ LEGATES from all parts of Great Britain (Scotland, Bristol, Birmingham, Billingham, London, Liverpool, Manchester, etc.) met at a chemical industries conference called by the Association of Scientific Workers on August 31 in Manchester to discuss the achievement of maximum technical effort behind war production and the problems of scientific staffs. This conference was the first of a series covering specific industries.

Speeches from the delegates showed the need and value of such conferences. Instances were cited of highly qualified scientific workers being engaged on non-essential work while production in other places was held up for lack of scientific personnel. Specific cases were given of lack of the systematic pooling of scientific information, leading to the holding up of production, and of the fullest use not being made of the resources of existing laboratories and equipment because of peace-time methods of organization.

The keynote of the conference was expressed by the chairman that only a greatly increased production could guarantee the support to the Allied forces which could defeat Fascism. It was generally agreed that the present hindrances to full utilization of all technical resources must be removed and all other questions, including the separate interests of both employers and staff, must be subordinate to this.

The following resolution was agreed upon unanimously :

"This conference of delegates from A.S.W. branches and groups in the chemical industries after discussion finds that the co-ordination and utilization of scientific and technical man-power is not commensurate with the effort needed in the present critical phase of the war. We, the delegates, pledge ourselves to initiate a campaign for maximum production. The organized activities of scientific and technical staff through the A.S.W. nationally and locally are necessary to implement this policy. We, therefore, propose the following programme : To ensure that

(1) The present position where all technical staff are not fully utilized on work essential to the war effort is quickly rectified ; (2) real pooling of technical information and facilities takes place between Government departments and industry ; (3) every incentive is given to increased effort on the part of technical staff by the removal of grievances attendant on nonpayment for overtime and irregular salary increments and holidays; (4) women occupying technical and scientific posts in industry receive the same salaries and opportunities as men doing the same type of work; (5) adequate training facilities be provided for inexperienced personnel to rectify the effect of transfer and enlistment of technical staff ; (6) the conditions of transference be safeguarded by consultation between representative organizations; (7) A.R.P. and safety organizations be under democratic control as envisaged by Government legislation.

To carry this programme into effect we propose the following action: (1) the calling of local works and laboratory meetings to apply the programme to local conditions ; (2) initiation of approaches by the A.S.W. to all organizations concerned with production including managements of firms and national and regional production boards; (3) the closest co-operation with other trade unions ; (4) strengthening of the A.S.W. as representing all technical and scientific staff."

\section{FORTHCOMING EVENTS}

Tuesday, September I6 The Farmers' Club (at the Royal Eropire Society, 'raven Street,
London, W.C.2) at 3 p.m.-Mr. W. S. Mansfield : "The Maintondon, W.C.2), at 3 p.m.-Mr. W. S,

\section{APPOINTMENTS VACANT}

AppLICATIONS are invited for the following appointments on or before the dates mentioned :

Teacher (Male) of Chemistry and Physics in the Londonderry Municipal Technical College-The Director of Edncation, Education Office, 5 Guildhall Street, Londonderry (September 20).

Assistan't Lecturer in SCIEnce, Mathematios and Drawing in the Halesowen County Technical School-The Secretary, Halesowen Higher Education Committee, 21 Great Cornbow, Halesowen, Worcestershire (September 20)

REGISTRAR at the Huddersfleld Technical College-The Director of Education, Education Offices, Peel Street, Huddersfield (September 30). LECTURER IN NEUROPATHOLOGY AND NEUROPATHOLOGIST to Mental Hospitals of New South Wales-The Secretary, Universities London, W.C.1.

LIVESTock OFFICER-The Secretary, Land Settlement Association, LIVESTOCK OFFICER-The Secretary, Lan
Ltd., 43 Cromwell Road, London, S.W.7.

\section{REPORTS AND OTHER PUBLICATIONS}

(not included in the monthly Books Supplement)

\section{Great Britain and Ireland}

Proceedings of the Royal Society of Edinburgh. Section B : Biology. Vol. 61, Part 1, No. 9: Cytological Analysis of Chromosome Behaviour in Three Breeds of Dogs. By I. A. Ahmed. Pp. 107-118. (Edinburgh and London: Oliver and Boyd.) 18 .

Freshwater Biological Association of the British Empire.) Ninth Annual Report for the year ending 33st Mareh, 1941. Pp. 54. (Ambleside : Freshwater Biological Association of the British Empire. [188

Proceedings of the Royal Society of Edinburgh. Section A (Mathematical and Physical Sciences.) Vol. 61, Part 1, No. 6: Generating Functions of Certain Continuous Orthouonal Systems By A. Erdélyi. Pp. 61-70 9d Vol, 61, Part 1, No 7: The Clear-Day Barometric Pp. 61-70. 9d. Vol. 61, Part 1, No. and at Ben Nevis. By $\mathrm{T}$. Tan

\section{Other Countries}

Indian Central Jute Committee. Teehnological Research Memoir No. 2: The Relation between the Physical Fibre Characters and th Spinning Quality of Jute, 1. By C. R. Nodder, K. R. Sen and B. K. Chakrabarti. Pp. $20+4$ plates. (Calcutta: Indian Central Jute Committee.) 1 rupee ; 28 .

Records of the Geological Survey of India. Vol. 76, Bulletins of Economic Minerals, No. 3: Strontium, By M. S. Krishnan. Pp. 16 (Calcutta: Geological Survey of India.) 6 annas; $7 d$. Proceedings of the United States National Museum. Vol. 90 Proceedings of the United States National Museum. Vol. 90, No. 3111: The Chicora (Butler County, Pa.) Meteorite. By F. W. Preston, E. P. Henderson ard James R. Randolph. Pp. 387-416.
(Washington, D.C.: Government Printing Office.)
[158 Forest Research in India and Burma, 1939-40. Part 1: The Forest Research Institute, Dehra Dun. Pp. iii + 133. (Delhi : Manager of Publications.) 3 rupees; 58 .

Smithsonian Institution: Bureau of American Ethnology. Bulletin 128: Anthropological Papers, Nos. 13-18. Pp. xii $+368+52$ plates. Department of Scientific and Industrial Research, New Zealand. Dominion Observatory Bulletin No. S-60: Ground Tilt at Wellington, New Zealand. By R. C. Hayes and R. D. Thompson. Pp. 18. (Wellington: Government Printer.)

Proceedings of the United States National Museum. Vol. 90, No. 3114: A New Genus of Sea Stars (Plazaster) from Japan, with a Note on the Genus Parasterina. By Walker K. Fisher. Pp. 447-456 + plates $66-70$. (Washington, D.C. : Government Printing Office.) [198 Queen Victoria Memorial, Salisbury, Southern Rhodesia. Annual Report for the Year ended 31st March 1941. Pp. 8. (Salisbury : Queen Victoria Memorial.)

Editorial and Publishing Offices

MACMILLAN \& CO., LTD.

ST. MARTIN'S STREET, LONDON, W.C.2

Telephone: Whitehall a31 Telegraphic Address: Phusis Lesquare London Advertisements should be addressed to

T. G. Scott \& Son, Ltd., Three Gables, London Read, Merstham, Surrey Telephone: Merstham 316

The annual subseription rate is 64106 , payable in advance, Intand or Abroed All rights reserved. Registered as a Newspaper at the General Post Office 